\title{
Pelaksanaan FETP Sampai Pemunculan ETMP di Indonesia
}

\section{The Implementation of FETP Until The Appearance of ETMI In Indonesia}

\section{Oleh: Buchari Lapau *}

*Ketua Kolegium Epidemiologi, Majelis Kolegium Kesehatan Masyarakat Indonesia dan Guru Besar Epidemiologi pada beberapa universitas di Indonesia

\section{Semboyan: Boleh Belajar Dari Luar Negeri Namun Berusaha Sebagai Pencipta Untuk Mengatasi Masalah Bangsa}

\begin{abstract}
Abstrak
Makalah ini menjelaskan FETP yang berasal dari Amerika Serikat telah dilaksanakan di Indonesia, tetapi tak sepenuhnya dilaksanakan seperti aslinya sehingga tidak diakui secara internasional. Dari pengalaman dalam pelaksanaan FETP dalam Proyek ICDC (Intensified Communicable Disease Control), anak bangsa sendiri dapat menciptakan kurikulum untuk Program Magister Kesehatan Masyarakat Peminatan Epidemiologi Terapan untuk Manajemen Pelayanan/Program (ETMP). Kemudian anak bangsa sendiri dapat pula menciptakan Standar Profesi Epidemiolog Kesehatan yang merupakan standar untuk pendidikan profesi satu tahun setelah SKM (Sarjana Kesehatan Masyarakat). Diharapkan supaya PAEI, Kolegium Epidemiologi, Majelis Kolegium Kesehatan Masyarakat Indonesia (MKKMI) dan Universitas melakukan pendekatan kepada BPSDM Depkes, Menko Kesra, Dit Jen. Pendidikan Tinggi, BNSP (Badan Nasional Sertifikasi Profesi), dan lain-lain sedemikian rupa sehingga pemerintah mengabulkan berdirinya Pendidikan Profesi Epidemiolog Kesehatan dan lulusannya dapat melanjutkan pendidikan ke Program Studi Magister Kesehatan Masyarakat Peminatan ETMP dan FETP. Kurikulum Peminatan FETP yang sudah ada perlu ditambah dengan epidemiologi dan penanggulangan bencana.
\end{abstract}

Kata Kunci : FETP, Standar Profesi Epidemiologi, ETMP

\section{Abstract}

This paper clarifies the FETP (Field Epidemiology Training Program) originated from USA has been implemented in Indonesia, but it had not been implemented originally, so that it had not been recognized internationally. The experience in the implementation of FETP in the Intensified Communicable Disease Control (ICDC) Project, stimulated Indonesian citizens to create the curriculum for the Master Program of Public Health Majoring in Applied Epidemiology for the Management of Health Program/Services (ETMP). Then, Indonesian citizens can create the Professional Standard of Epidemiologist, which is the standard for professional education to be epidemiologist one year after the academic degree of SKM (Bachelor in Public Health). It is necessary for the Indonesian Epidemiology Association (PAEI), Kolegium Epidemiologi, Majelis Kolegium Kesehatan Masyarakat Idonesia (MKKMI) and universities to approach Human Resources Development Institute of Ministry of Health, Ministry of Welfare, Directorate General of High Education, BNSP (national professional certificate institute), etc, in such a way so that government approves the establishment of Professional Education to be Epidemiologist, who can continue their education to the Master Program of Public Health Majoring in ETMP and FETP. The existing curriculum of Majoring in FETP is necessary to be completed with the control and epidemiology of disaster.

Key Word : FETP, Profesional Standard of Health Epidemiologist, ETMP.

Alamat Korespondensi : Buchari Lapau, STIKes Hang Tuah Pekanbaru, Ketua Prodi Pascasarjana IKM, Jalan Mustafa Sari No 5 Tangkerang Selatan Pekanbaru Riau, Hp : 08129210225, email : buchlap@yahoo.com. 


\section{A. Pendahuluan}

Pada tanggal 29 Juli 2009, Kantor Menko Kesra RI melakukan Pertemuan Ilmiah di Yogyakarta yang antara lain membahas Standar profesi Epidemiolog Kesehatan, yang merupakan suatu standar bagi mereka yang akan mengikuti Pendidikan Profesi Epidemiologi yang lamanya 1 tahun setelah lulus SKM (Sarjana Kesehatan Masyarakat). Standar Profesi Epidemiologi terdiri atas standar pendidikan untuk menghasilkan lulusan yang mempunyai standar kompetensi atas dasar standar pelayanan epidemiologi yang ditetapkan oleh departemen kesehatan. Sebelumnya pendidikan profesi sudah dilakukan di Indonesia yaitu apa yang disebut Field Epidemology Training Program (FETP), yang merupakan suatu pendidikan profesi yang dikembangkan ke seluruh dunia yang berpusat di Center of Disease Control (CDC) Atlanta, Amerika Serikat.

Dalam acara diskusi tentang standar tersebut muncul pertanyaan dari salah seorang yang hadir dalam pertemuan ini yang menanyakan apakah ada standar atau kurikulum internasional atau dari negara lain tentang Standar Profesi Epidemiolog Kesehatan. Standar ini tidak dibuat atas dasar standar profesi yang berasal dari luar negeri tapi diciptakan di Indonesia sendiri dalam rangka memenuhi kebutuhan terhadap pendidikan epidemiologi untuk menjawab tantangan masalah-masalah yang berkaitan dengan kesehatan untuk mana prinsip dan metode epidemiologi perlu dimanfaatkan.

Moderator untuk penyajian standar ini yaitu Dr. dr. Armyn Nurdin, MSc yang adalah seorang Pejabat dari Menko Kesra RI menutup sidang yang sebelumnya menyatakan bahwa pembahasan mengenai Standar Profesi Epidemiolog Kesehatan ini merupakan tonggak sejarah untuk pengembangan pendidikan profesi epidemiologi yang berasal dari ciptaan anak bangsa untuk kebutuhan bangsa sendiri. Tidak selalu cara mengatasi masalah nasional kita harus menjiplak dari luar negeri, bahkan kita sendiri sebagai anak bangsa perlu menciptakan sendiri apa yang dibutuhkan oleh bangsa dan negara kita. Bukan tidak mungkin bahwa apa yang kita ciptakan dapat dilaksanakan secara nasional, regional bahkan global.

FETP merupakan salah satu peminatan dari Program Studi Magister (S2) Kesehatan Masyarakat; di samping itu ada pula Program Pendidikan Epidemiologi setingkat Magister yang disebut Program Magister Studi Kesehatan Masyarakat Peminatan Epidemiologi Terapan untuk Manajemen Pelayanan/Program (ETMP). Sehubungan dengan semangat tersebut diatas, timbul pertanyaan kenapa sampai ada Program Studi Magister Kesehatan Masyarakat Peminatan ETMP, apa perbedaannya dari FETP, dan apa kaitannya dengan Pendidikan Profesi Epidemiolog Kesehatan dalam rangka pemanfaatan epidemiologi untuk pelayanan dan program kesehatan, dan program nasional lainnya. Berikut ini adalah informasi untuk menjawab pertanyaan tersebut.

\section{B. Field Epidemiology Training Program (FETP)}

FETP yang merupakan salah satu program pelatihan untuk Epidemiologi Lapangan (Field Epidemiology) yang dapat didefinisikan (Goodman and Buehler, 1996) sebagai penerapan epidemiologi di bawah perangkat kondisi umum sebagai berikut:

- Masalah yang diselidiki tidak diharapkan datangnya

- Tindakan untuk mengatasi masalah tersebut dilakukan sesegera mungkin

- Ahli Epidemiologi Lapangan mesti melakukan perjalanan dan bekerja di 
lapangan untuk menyelidiki dan mengatasi masalah tersebut

- Luasnya penyelidikan seakan-akan terbatas karena diperlukan tindakan tepat pada waktunya.

Ahli Epidemiologi Lapangan yang terutama melakukan penyeldikan lapangan tentang masalah-masalah yang akut masih menggunakan banyak karakteristik dari studi epidemiologi yang direncanakan secara prospektif, namun ada perbedaannya sekurang-kurangnya sebagai berikut: Pertama, karena penyelidikan lapangan sering mulai tanpa hipotesis yang jelas, maka yang dilakukan studi deskriptif yang hanya dapat digunakan untuk mengembangkan hipotesis, yang perlu dibuktikan dengan studi analitik. Kedua, kalau masalah akut terjadi, masyarakat harus dilindungi dengan segera; karena itu penyelidikan lapangan tak dapat dilakukan dengan pengumpulan data yang baik, sehingga belum dapat dilakukan analisa untuk merumuskan kegiatan kesehatan masyarakat dalam jangka panjang. Ketiga, penyelidikan lapagan mengundang kita untuk mengumpulkan, mengolah dan menganalisis data menghasilkan informasi untuk tindakan segera dari pada merumuskan pertanyaan penelitian lebih lanjut. Konsep dan metode yang digunakan dalam penyelidikan lapangan berasal dari kedokteran klinik, epidemiologi, ilmu laboratorium, teori keputusan, keterampilan dalam berkomunikasi, dan logika.

FETP yaitu pendidikan untuk menghasilkan Ahli Epidemiologi Lapangan (Field Epidemiologist) tentu pertama kali dilakasanakan di CDC Atlanta, Amerika Serikat. Konon ada berita bahwa pelaksanaan FETP di luar Amerika Serikat pertama kali di Thailand. Pada tahun 1981, satu tim yang terdiri dari Fakultas Kesehatan Masyarakat Universitas Indonesia yang Dekannya dr.
Does Sampurno, MPH mengirim dr. Anhari Achadi, SKM selaku Pudek Akad FKMUI dan dr. Buchari Lapau MPH selaku Ketua Jurusan Epidemiologi FKMUI, dan dari Direktorat Jenderal Pencegahan dan Pemberantasan Penyakit Menular (P3M) Departemen Kesehatan (Depkes) yang Dir. Jen. nya dr. Adhyatma MPH mengirim dr. Brotowasisto MPH selaku Direktur Epidemiologi \& Karantina dan dr. Karyadi MSc selaku Kepala Subdit Surveilens Epidemiologi, yang ditemani oleh WHO Representative Indonesia, Dr. ElZawahri, untuk meninjau pelaksanaan FETP di Bangkok, Thailand.

Pada tahun 1982 berdirilah FETP di Indonesia, yang pesertanya adalah para dokter, dilaksanakan oleh Direktorat Jenderal P3M Depkes di Jakarta, yang Direktur Pendidikannya langsung berasal dari CDC Atlanta. Lulusan FETP yang tidak mendapatkan gelar akademis, mendapatkan pelajaran di kelas hanya beberapa bulan, lalu mereka mengikuti kegiatan lapangan yaitu surveilens dan penyeldikan Kejadian Luar Biasa atau wabah di seluruh Indonesia. Dengan sistem dan cara pendidikan seperti ini para peserta belajar sambil mendapat pengalaman dan mendapat pengalaman sambil belajar sehingga dihasilkan para lulusan yang siap pakai menyandang profesi sebagai penyelidik epidemiologi lapangan.

Beberapa tahun setelah FETP berdiri di Indonesia, minat para peserta yang berasal dari dokter berkurang karena FETP tak dapat memberikan gelar setingkat Magister, sehingga FETP menerima peserta tidak hanya dari dokter tetapi juga mereka yang bergelar Sarjana Kesehatan Masyarakat (SKM). Sehubungan dengan pemenuhan permintaan supaya tamatan FETP mendapatkan gelar Magister, maka Departemen Kesehatan mengadakan kerja sama dengan Universitas Indonesia mulai tahun 1986 untuk 
melaksanakan FETP, yang pelaksanaannya 4 semester di univeritas dan 1 semester di Direktorat Jenderal P3M di mana mereka melakukan kegiatan lapangan terutama penyelidikan KLB atau wabah di seluruh Indonesia. Kemudian Departemen Kesehatan melakukan FETP bekerja sama dengan Universitas Gajah Mada. Lulusan FETP yang bekerja sama dengan universitas memang mendapatkan gelar akademis namun dianggap kurang berpengalaman dalam melakukan penyelidikan lapangan.

\section{FETP dalam Proyek ICDC}

Pada tahun 1995, Pemerintah Indonesia merencanakan kerjasama dengan Asian Development Bank untuk mendirikan Proyek ICDC (Intensified Communicable Disease Control), yang kegiatannya dilakukan terutama dalam rangka desentralisasi di tingkat kabupaten/kota. Proyek ICDC ini terdiri atas tiga bagian yaitu 1) Intensifikasi pelaksanaan beberapa program pemberantasan penyakit menular, 2) Manajemen program pemberantasan penyakit menular dalam rangka desentralisasi di tingkat kabupaten/kota; dan 3) Pembangunan kemitraan lintas sektor untuk menyokong pemberantasan penyakit menular (Lapau, 2003).

Untuk melaksanakan Proyek ini di tingkat kabupaten/kota didirikan Tim Epidemiologi Kabupaten (TEK) yang langsung bertanggung jawab kepada Kepala Dinas Kesehatan Kabupaten/Kota. Sejalan dengan itu, di tingkat propinsi didirikan pula Tim Epidemiologi Propinsi (TEP), dan di tingkat nasional yaitu di Departemen Kesehatan didirikan Tim Epidemiologi Nasional (TEN). Pimpinan dan staf dari TEK itu harus mempunyai kemampuan untuk melaksanakan kegiatan-kegiatan yang berkaitan dengan 3 Bagian dari Proyek ICDC. Untuk Bagian Intensifikasi Pemberantasan Penakit Menular dibutuhkan kemampuan Surveilens Epidemiologi dan Penelitian Operasional, untuk Bagian Penguatan Manajemen Dinas Kesehatan Kabupaten diperlukan kemampuan Sistem Informasi Manajemen Kesehatan dan Manajemen Mutu/Audit, dan Bagian Kemitraan untuk mana diperlukan kemampuan Komunikasi dan Advokasi, dapat menyokong Intensifikasi Pemberantasan Penyakit Menular dan Penguatan Manajmen Kesehatan Kabupaten (Lapau, 2003).

Fungsi dari TEK itu adalah 1) Untuk menyediakan informasi dan bukti kepada Kepala Dinas Kesehatan Kabupaten sebagai bahan pertimbangan untuk pengambilan keputusan. dan 2) memberikan rekomendasi tentang aspek teknis supaya manajer program melakukan koreksi dan perbaikan sesegera mungkin (NEST, 2002). Kedua fungsi tersebut dikombinasikan menjadi Peranan TEK dalam Pengambilan Keputusan Berdasar Bukti yaitu menghasilkan Bukti yang berguna bagi Kepala Dinas Kesehatan Kabupaten untuk mengambil keputusan dari mana dibuat Perencanaan Strategis dan Perencanaan Operasional. Perencanaan Strategis dikomunikasikan dan diadvokasikan ke DPRD Kabupaten dan Bupati melalui BAPPEDA dan lintas sektor supaya dapat diterima dan dilaksanakan oleh Dinas Kesehatan Kabupaten dan bantuan intervensi oleh sektor-sektor lain (bukan kesehatan). Perencanaan operasional melalui Kepala Dinas Kesehatan Kabupaten/Kota dikomunikasikan kepada Kepala Subdinas dan selanjutnya Penanggung Jawab Program dalam rangka koreksi dan perbaikan perencanaan, pelaksanaan dan pemantauan program yang bersangkutan.

Untuk mengisi tenaga pimpinan dan staf Tim Epidemiologi Kabupaten/Kota tersebut, maka diperlukan tenaga epidemiologist yang dididik melalui Field Epidemiology Training Program (FETP) yang dilaksanakan oleh 
Program Pascasarjana Kesehatan Masyarakat Universitas Indonesia lalu Fakultas Kesehatan Masyarakat Universitas Indonesia, Jurusan Kesehatan Masyarakat Fakultas Kedokteran Universitas Gajah Mada, dan terakhir Fakultas Kesehatan Masyarakat Universitas Airlangga. Pelaksanaan FETP oleh masingmasing universitas tidak sama dengan pelaksanaan FETP seperti tahun 1982 atau yang dilaksanakan di CDC Atlanta dan di Thailand. Kurikulum diarahkan sedemikian rupa sehingga para lulusan mempunyai kemampuan khususnya menilai, merencanakan dan melaksanakan surveilens, penelitian operasional, manajemen mutu/audit, komunikasi dan advokasi di samping mata ajaran lain dalam rangka program magister. Para mahasiswa mendapatkan pula mata ajaran investigasi wabah 2 sks, namun para mahasiswa susah mendapat kesempatan melakukan penyelidikan KLB/Wabah di seluruh Indonesia karena mereka bekerja hanya di tingkat kabupaten yang bersangkutan.

\section{Standar Profesi Epidemiolog Kesehatan}

Ikatan Ahli Kesehatan Masyarakat Indonesia (AKMI) telah membentuk Majelis Kolegium Kesehatan Masyarakat (MKKMI), yang pada tanggal 9-10 Mei 2008 membentuk 8 (delapan) Kolegium antara lain Kolegium Epidemiologi. Menurut ketentuan dari MKKMI, kewenangan kolegium termasuk Kolegium Epidemiologi (PAEI, 2008) adalah sebagai berikut:

1. Mengembangkan dan menetapkan Kurikulum dan Program Pendidikan

2. Merencanakan dan melaksanakan ujian seleksi kepada mereka yang ingin mendapatkan sertifikasi epidemiolog kesehatan
3. Melakukan akreditasi terhadap institusi yang menyelenggarakan pendidikan profesi epidemiolog kesehatan

4. Membentuk organisasi profesi: untuk kewenangan ini bagi disiplin epidemiologi, sejak 14 Mei tahun 1989 berdiri Perhimpunan Ahli Epidemiologi Indonesia (PAEI)

5. Memantapkan sebutan profesi: untuk kewenangan ini, profesinya disebut Eidemiolog Kesehatan

6. Memilih dan menetapkan institusi yang menyelenggarakan pendidikan profesi

7. Menetapkan lembaga sertifikasi profesi yang perlu bekerja sama dengan BPSDM Depkes, Badan Nasional Stanfadrdisasi Profesi (BNSP) dan Departemen Tenaga Kerja

8. Menetapkan sertifikat dosen epidemiologi

Sehubungan dengan kewenangan tersebut, maka Kolegium Epidemiologi telah dapat menghasilkan Standar Profesi Epidemiolg Kesehatan yang meliputi standar pelayanan, standar kompetensi dan standar pendidikan. Standar Pelayanan dalam rangka penyusunan Standar Profesi Epidemiolog Kesehatan tersebut didasarkan pada Tugas Pokok dan Rincian Kegiatan Tenaga Jabatan Fungsional Epidemiologi yang dirumuskan oleh Direktorat Jenderal Pengendalian Penyakit dan Penyehatan Lingkungan Departemen Kesehatan RI di mana tertulis bahwa tenaga terampil dan tenaga ahli dari Jabatan Fungsional Epidemiologi Kesehatan dapat melakukan kegiatan-kegiatan sebagai berikut:

1. Melakukan persiapan pelaksanaan kegiatan

2. Melakukan surveilens epidemiologi

3. Melakukan penyelidikan KLB atau Wabah

4. Melaksanakan Sistem Kewaspadaan Dini 
5. Melaksanakan pencegahan dan pemberantasan penyakit

6. Melakukan pemberdayaan masyarakat

Dalam satu pertemuan yang dilakukan oleh PAEI, atas dasar keilmuan epidemiologi, tugas pokok dan rincian kegiatan tenaga jabatan funsional epidemiologi tersebut di atas, maka telah ditetapkan Profil Lulusan dari Program Studi Profesi Epidemiolog Kesehatan yaitu mempunyai kemampuan untuk berperan sebagai berikut:

1. Melakukan identifikasi dan pemecahan masalah

2. Merencanakan, melaksanakan dan menilai sistem surveilens

3. Merencanakan dan melaksanakan kewaspadaan dini dan melakukan penyelidikan Kejadian Luar Biasa atau Wabah

4. Merencanakan, melaksanakan, memantau dan menilai program kesehatan termasuk program pemberantasan dan pencegahan penyakit

5. Merencanakan dan melaksanakan manajemen mutu/audit

6. Merencanakan, melaksanakan dan menilai pendidikan dan pelatihan termasuk pemberdayaan masyarakat

7. Berperilaku sebagai Komunikator dan Advokator

8. Menguasai Teknologi Informasi.

Peran tersebut didistribusikan menurut Kurikulum Berbasis Kompetensi (KBK) yang terdiri atas Kurikulum Inti (butir 1 sampai dengan butir 5 tersebut di atas) dan Kurikulum Pendukung (butir 6 sampai dengan butir 8 di atas). Peran tersebut dioperasionalkan menjadi fungsi, untuk mana diperlukan kompetensi tertentu. Untuk mencapai kompetensi tersebut diperlukan pendidikan dengan menggunakan KBK yang termasuk dalam kelompok Mata Kuliah
Keilmuan dan Keterampilan (MKK) yaitu Learning To Know, Mata Kuliah Keahlian Berkarya (MKB) yaitu Learning To Do, Mata Kuliah Perilaku Berkarya (MPB) yaitu Learning To be, dan Mata Kuliah Berkehidupan Bermasyarakat (MBB) yaitu Learning To Live Together.

Mempelajari MKK dan MKB akan memperoleh kemampuan analisis dan sintesis, menguasai komputer dan teknologi informasi, mengelola sesuatu dengan berbagai kemungkinan, dapat berkomunikasi secara lisan dan tertulis. Studi MPB akan menumbuhkan sikap kepemimpinan, kerjasama dan dapat bekerja dengan saling tukar budaya. Dengan Studi MBB, peserta berkenalan dengan sifat pekerjaan terkait sehingga terlatih dalam etika kerja, memahami makna globalisasi dan fleksibel terhadap pilihan pekerjaaan.

\section{E. Pembahasan \\ 1. Kenapa muncul Program Studi Magister Peminatan ETMP?}

Dari informasi tersebut diatas baik tentang FETP ataupun FETP dalam Proyek ICDC jelas bahwa apa yang dimaksud FETP dalam Proyek ICDC, bukanlah FETP yang original, karena kurikulum yang disusun untuk menghasilkan para lulusan dalam rangka Proyek ICDC meliputi manajemen pelayanan kesehatan tingkat kabupaten, manajemen intensifikasi pemberantasan penyakit, dan komunikasi \& advokasi dalam rangka kemitraan dengan DPRD, BAPPEDA dan lintas sektor. Dari pengalaman penciptaan kurikulum epidemiologi dalam Proyek ICDC inilah yang berorientasi pada manajemen, maka dibentuk kurikulum Program Studi Magister Kesehatan Masyarakat Peminatan Epidemiologi Terapan untuk Manajemen Pelayanan/Program (ETMP). Supaya jelas apa yang dimaksud dengan Peminatan ETMP, 
berikut ini terlihat perbedaan antara ETMP dan FETP.

\section{Perbedaan FETP dan ETMP}

FETP adalah Peminatan Program Latihan Epidemiologi Lapangan yang dilaksanakan di Indonesia dalam proyek ICDC tidak sesuai dengan aslinya sehingga tak diakui secara internasional. Epidemiologi Lapangan (Field Epidemiology), telah di jelaskan pada halaman sebelumnya yang berbeda dari pada ETMP (Epidemiologi Terapan Untuk Manajemen Program Pelayanan).

ETMP adalah Peminatan dalam Program Magister Kesehatan Masyarakat, yang merupakan epidemiologi terapan untuk manajemen program/pelayanan yang diperinci sebagai berikut:

1. Masalah yang dipelajari sudah berulang atau baru terjadi

2. Hasil studi memberikan informasi dan bukti yang dapat digunakan untuk perencanaan strategis dan perencanaan operasional

3. Ahli Epidemiologi-Manajemen mendampingi Kepala Dinas Kesehatan Kabupaten/ Kota untuk melakukan advokasi tentang rencana kesehatan strategis ke DPRD, BAPPEDA dan lintas sektor, dan membimbing petugas epidemiologi di kabupaten, kecamatan dan desa dalam rangka menghasilkan informasi dan bukti untuk perencanaan operasional dan penyelidikan KLB

4. Melakukan penelitian operasional dalam rangka peningkatan mutu dan pemanfaatan pelayanan serta manajemen strategis

\section{Kaitan Pendidikan Profesi Epidemiolog Kesehatan dengan Peminatan ETMP}

Seperti yang yang dijelaskan seperti tersebut diatas dapatlah dimengerti bahwa Standar Profesi Epidemiolog Kesehatan juga hasil ciptaan anak bangsa. Di samping itu dapat disimpulkan bahwa lulusan dari Pendidikan Profesi Epidemiolog Kesehatan yaitu satu tahun setelah SKM (Sarjana Kesehatan Masyarakat) mampunyai kompetensi dalam mengidentifikasi masalah terutama dengan surveilens, manajemen program dan manajemen mutu pelayanan, melakukan advokasi, dan membangkitkan pemberdayaan masyarakat. Lulusan pendidikan profesi ini bila melanjutkan pendidikan satu tahun lagi untuk mempelajari metodologi penelitian, menulis tesis dan laporan ilmiah dan merencanakan manajemen strategis sehingga mendapat gelar Akademis yang disebut Magister Kesehatan Masyarakat Peminatan ETMP.

\section{Kaitan Pendidikan Profesi Epidemiolog Kesehaatan dengan FETP}

Karena dalam Pendidikan Profesi Epidemiolog Kesehatan telah dilakukan pekerjaan lapangan dalam rangka melaksanakan proses belajar mengajar dengan kelompok mata kuliah MKK dan MKB di kelas, dan kelompok mata kuliah MPB dan MBB di lapangan yaitu di Wilayah Dinas Kesehatan Kabupaten/kota, maka lulusan dari Program Pendidikan Profesi ini dapat melanjutkan pendidikannya setingkat Magister Kesehatan Masyarakat Peminatan FETP, dalam mana para mahasiswa mengambil satu semester untuk melakukan penyelidikan KLB/Wabah di seluruh Indonesia, dan belajar satu semester lagi untuk belajar metodologi penelitian dan pembuatan tesis.

\section{Indonesia, rawan bencana}

Indonesia yang adalah satu negara kepulauan yang rawan bencana seperti gempa bumi, tsunami, kebakaran hutan menimbulkan asap, dan lain-lain di samping KLB dan wabah penyakit antar regional dan 
internasional, perlu mendapat perhatian sedemikian rupa oleh pemerintah melalui suatu Badan Pengendalian Bencana. Salah satu unsur dalam Badan tersebut adalah Sektor Kesehatan khususnya untuk Penyelidikan Epidemiologi. Karena itu kurikulum FETP di samping berisi Investigasi KLB/wabah, International Health Regulation, juga epidemiologi dalam penanggulangan bencana yang dipraktekan pada tingkat propinsi dan tingkat nasional, bahkan tingkat regional dan internasional.

\section{F. Kesimpulan dan Saran}

PAEI, Kolegium Epidemiologi, Majelis Kolegium Kesehatan Masyarakat Indonesia dan Universitas berusaha mendekati BPSDM Depkes, Menko Kesra dan Dit. Jen. Pendidikan Tinggi, BNSP, dan lain-lain sehingga pemerintah.

1. Mendirikan Pendidikan Profesi Epidemiolog Kesehatan (pendidikan 1 tahun setelah SKM), yang merupakan ciptaan anak bangsa sendiri

2. Lulusan Pendidikan Profesi Epidemiolog Kesehatan dapat melanjutkan pendidikan akademis satu tahun lagi untuk mendapatkan gelar Magister Kesehatan Masyarakat Peminatan ETMP, yang kurikulumnya merupakan ciptaan anak bangsa pula

3. Lulusan Pendidikan Profesi Epidemiolog Kesehatan dapat melanjutkan pendidikan akademis satu tahun lagi untuk mendapatkan gelar Magister Kesehatan Masyarakat Peminatan FETP

4. Peminatan FETP di samping mempunyai kurikulum yang sudah ada perlu ditambah tentang epidemiologi dalam penanggulangan bencana.

\section{G. Daftar Pustaka}

Goodman, Richard A. and James W. Buehler. Field Epidemiology Defined, Field Epidemiology,Ed. Michael B. Gregg, New York: Oxford University, 1996.

Keputusan MUNAS PAEI Nomor 07/MUNAS/PAEI/2008. Standar Kompetensi Epidemiolog Kesehatan, Jakarta: MIKE Tahun VIII No. 1, 2009.

Lapau, Buchari. Function of District Epidemiological Surveillance Team, The Seven Selected Individual Reports Concerning Epidemiological Surveillance, District Epidemiological Surveillance Team and Epidemiological Support for Planning, Jakarta: Proyek ICDC, 2003.

Lapau, Buchari.The Role of DEST in Evidence Based Decision Making, The Seven Selected Individual Reports Concerning Epidemiological Surveillance, District Epidemiological Surveillance Team and Epidemiological Support for Planning, Jakarta: Proyek ICDC, 2003.

NEST, Pedoman Operasioal Tim

Epidemiologi Kabupaten/Kota, Jakarta: Dit. Jen PPM dan KL, 2002. 